\title{
Activity-Dependent Local Translation of Matrix Metalloproteinase-9
}

\author{
Magdalena Dziembowska, ${ }^{1}$ Jacek Milek, ${ }^{1}$ Aleksandra Janusz, ${ }^{1}$ Emilia Rejmak, ${ }^{1}$ Ewelina Romanowska, ${ }^{1}$ \\ Tomasz Gorkiewicz, ${ }^{1,3}$ Adrian Tiron, ${ }^{2}$ Clive R. Bramham, ${ }^{2}$ and Leszek Kaczmarek ${ }^{1}$ \\ ${ }^{1}$ Laboratory of Neurobiology, The Nencki Institute, 02-093 Warsaw, Poland, ${ }^{2}$ Department of Biomedicine and KG Jebsen Centre for Research on \\ Neuropsychiatric Disorders, University of Bergen, N-5009 Bergen, Norway, and ²Department of Biophysics, Warsaw University of Life Sciences SGGW, \\ 02-787 Warsaw, Poland
}

Local, synaptic synthesis of new proteins in response to neuronal stimulation plays a key role in the regulation of synaptic morphogenesis. Recent studies indicate that matrix metalloproteinase-9 (MMP-9), an endopeptidase that regulates the pericellular environment through cleavage of its protein components, plays a critical role in regulation of spine morphology and synaptic plasticity. Here, we sought to determine whether MMP-9 mRNA is transported to dendrites for local translation and protein release. First, dendritic transport of MMP-9 mRNA was seen in primary hippocampal neuronal cultures treated with glutamate and in dentate gyrus granule cells in adult anesthetized rats after induction of long-term potentiation. Second, rapid, activity-dependent polyadenylation of MMP-9 mRNA; association of the mRNA with actively translating polysomes; and de novo MMP-9 protein synthesis were obtained in synaptoneurosomes isolated from rat hippocampus. Third, glutamate stimulation of cultured hippocampal neurons evoked a rapid (in minutes) increase in MMP-9 activity, as measured by cleavage of its native substrate, $\beta$-dystroglycan. This activity was reduced by the polyadenylation inhibitor, thus linking MMP-9 translation with protein function. In aggregate, our findings show that MMP-9 mRNA is transported to dendrites and locally translated and that the protein is released in an activity-dependent manner. Acting in concert with other dendritically synthesized proteins, locally secreted MMP-9 may contribute to the structural and functional plasticity of the activated synapses.

\section{Introduction}

Matrix metalloproteinase-9 (MMP-9) is an endopeptidase that regulates the pericellular environment through the cleavage of protein components of the extracellular matrix. It is expressed in neurons and was shown to be secreted after synaptic stimulation (Dzwonek et al., 2004; Rivera et al., 2010). Several lines of evidence suggest a critical role for MMP-9 in synaptic changes associated with learning and memory. It has been shown that MMP-9 is rapidly and transiently activated in an NMDA receptor- and a protein synthesis-dependent manner during the late phase of long-term potentiation (LTP) (Nagy et al., 2006). MMP-9 is activated perisynaptically after LTP induction and is required for LTP maintenance (Bozdagi et al., 2007; Meighan et al., 2007; Okulski et al., 2007). Recent studies indicate also the important role of MMP-9 in shaping dendritic spine morphology (Wang et al., 2008; Bilousova et al., 2009; Michaluk et al., 2011). Hence, it has been suggested that MMP-9 can be secreted locally at the synapse, where it regulates extracellular focal proteolysis of spe-

\footnotetext{
Received Dec. 5, 2011; revised July 24, 2012; accepted Aug. 21, 2012.

Author contributions: M.D., C.R.B., and L.K. designed research; M.D., J.M., A.J., E.Re., E.Ro., T.G., and A.T. performed research; M.D., C.R.B., and L.K. analyzed data; M.D. wrote the paper.

This work was supported by Norwegian Financial Mechanism Grant PNRF96 (L.K. and C.R.B.), Polish Ministry of Science and Higher Education Grant N N301 033134 (M.D.), and the Foundation for Polish Science, FNP TEAM (L.K.).

Correspondence should be addressed to either Leszek Kaczmarek or Magdalena Dziembowska, Laboratory of Neurobiology, The Nencki Institute, Pasteura 3, 02-093 Warsaw, Poland. E-mail: leszek@nencki.gov.pl or stanczyk@nencki.gov.pl.

DOI:10.1523/JNEUROSCI.6028-11.2012

Copyright $\odot 2012$ the authors $\quad 0270-6474 / 12 / 3214538-10 \$ 15.00 / 0$
}

cific substrates leading to morphological changes of dendritic spines and proteolytic activation of cell-surface receptors, such as $\beta 1$-containing integrins, critical for LTP consolidation (Michaluk et al., 2007; Wang et al., 2008). In this context, MMP-9 is seen as a unique mediator of both structural and functional forms of synaptic plasticity. Szklarczyk et al. (2002) showed that kainate (KA) treatment results in upregulation of MMP-9 mRNA, protein, and enzymatic activity in hippocampal dentate gyrus (DG) and neocortex 6-24 h after seizures. Using low-resolution radioactive in situ hybridization, these authors showed activitydependent expression of MMP-9 mRNA within the molecular layer of DG, suggesting transport of induced MMP-9 mRNA into granule cell dendrites. This finding was substantiated by highresolution electron microscopy showing MMP-9 mRNA within dendritic spines of hippocampal neurons after KA (Konopacki et al., 2007). At present, however, there is no evidence for local translation of MMP-9 mRNA at synapses. Using a variety of complementary experimental strategies, the present study provides evidence for neuronal activity-dependent dendritic transport and local translation of MMP9 mRNA coupled with function of the newly synthesized protein.

\section{Materials and Methods}

Electrophysiology and LTP induction in anesthetized rats. A detailed description of the methods used for recording medial perforant-evoked field potentials has been published previously (Messaoudi et al., 2002, 2007). In brief, adult male Sprague Dawley rats weighing 250-300 g were anesthetized with urethane $(1.4-1.8 \mathrm{~g} / \mathrm{kg}$, i.p.), electrodes were inserted for selective stimulation of the medial perforant-path fibers in an angular 
bundle, and evoked field potentials in the hilar region of the dentate gyrus were recorded. Biphasic rectangular pulses of $150 \mu$ s duration were applied every $30 \mathrm{~s}$ throughout the experiment. The stimulation intensity for test pulses was set to elicit a population spike amplitude of $30 \%$ of the maximal response. The paradigm for high-frequency stimulation (HFS)LTP induction consisted of eight pulses at $400 \mathrm{~Hz}$, repeated four times, at $10 \mathrm{~s}$ intervals. Three sessions of HFS were given at intervals of $5 \mathrm{~min}$. Signals from the dentate hilus were amplified, filtered ( $1 \mathrm{~Hz}$ to $10 \mathrm{kHz})$, and digitized $(25 \mathrm{kHz})$. Acquisition and analysis of field potentials were accomplished using WorkBench software (DataWave Technologies), and the maximum slope of the fEPSP was measured. Two hours after HFS, the rats were perfused transcardially with $4 \%$ paraformaldehyde (PFA) in PBS. Brains were removed, postfixed in the same fixative for $24 \mathrm{~h}$, cryoprotected with $30 \%$ sucrose, and snap-frozen on dry ice. In situ hybridization was performed on $40-\mu \mathrm{m}$-thick free-floating sections as described for cultured neurons.

Primary hippocampal cultures and stimulation protocols. Hippocampi from $18 \mathrm{~d}$ rat embryos were dissected and dissociated using trypsin, and cells were plated at a density of 120,000 cells per 18 -mm-diameter coverslip (Karl Hecht GmbH and Co KG, Assistent) coated with $1 \mathrm{mg} / \mathrm{ml}$ poly-L-lysine (Sigma-Aldrich) and $2.5 \mu \mathrm{g} / \mathrm{ml}$ laminin (Roche) in Neurobasal-A supplemented with 2\% B27, $0.5 \mathrm{~mm}$ glutamine, $12.5 \mu \mathrm{M}$ glutamate, and $1 \%$ penicillin-streptomycin. All experiments were performed at 14-21 d in vitro (DIV). Cells were stimulated by bath application of glutamate $(50 \mu \mathrm{M})$, or the "synaptic protocol" was applied. Three hours before stimulation, TTX $(1 \mu \mathrm{M})$, CNQX $(40 \mu \mathrm{M})$, APV $(100 \mu \mathrm{M})$, and nifedipine ( $5 \mu \mathrm{M}$; all from Sigma-Aldrich) were added to cultured neurons. To activate the synaptic NMDA receptor (NMDAR), neurons were briefly plunged into the culture medium containing $50 \mu \mathrm{M}$ bicuculline and $5 \mu \mathrm{M}$ nifedipine to remove traces of TTX, APV, and CNQX; transferred into wells containing the same solution; and incubated at $37^{\circ} \mathrm{C}$ for the desired time, as described previously by Ivanov et al. (2006). To control the stimulation protocol, the induction of Erk kinase phosphorylation, specific only for synaptic NMDA receptor stimulation, was checked by Western blot for each experiment. In some experiments, cells were preincubated with $20 \mu \mathrm{M}$ cordycepin (Sigma-Aldrich) $10 \mathrm{~min}$ before the stimulation.

Fluorescence in situ hybridization and immunodetection. The coding sequence of MMP-9 mRNA (ATG probe) and 3'UTR (UTR probe) was reverse transcribed and cloned into a pDrive plasmid (PCR cloning kit; QIAGEN). Sense and antisense fluorescein-labeled riboprobes were generated from plasmids with SP6 or T7 polymerase sites. Hippocampal neurons were fixed in 4\% PFA, washed in PBS, and incubated in $1 \%$ $\mathrm{H}_{2} \mathrm{O}_{2}$ for $20 \mathrm{~min}$. Acetylation buffer $(0.1 \mathrm{M}$ triethanolamine, $0.25 \% \mathrm{HCl}$, $0.25 \%$ acetic anhydride) was applied for $15 \mathrm{~min}$ at room temperature. Next, cells were prehybridized for $3 \mathrm{~h}$ in a prehybridization solution (Sigma-Aldrich), followed by overnight hybridization at $70^{\circ} \mathrm{C}$ in a hybridization solution (Sigma-Aldrich) containing a 1:1 mix of ATG and UTR sense or antisense probes. Afterward, cells were washed in $0.5 \times$ SSC, with the first two washes performed for $1 \mathrm{~h}$ at $70^{\circ} \mathrm{C}$ and then five consecutive washes for $30 \mathrm{~min}$ at room temperature. Then, TNB blocking solution (TSA Plus System; PerkinElmer Life and Analytical Sciences) was applied for $1 \mathrm{~h}$. Cells were incubated with anti-fluorescein-POD (1:200; Roche Applied Science) and rabbit anti-FMR1 (sc-28739; Santa Cruz Biotechnology) antibodies overnight in $4^{\circ} \mathrm{C}$, washed with PBS with $0.1 \%$ Triton X-100 (PBST), and incubated with Alexa 488-conjugated goat anti-rabbit IgG secondary antibody (1:1000; Invitrogen). The hybridization signal was amplified with the Cy3 TSA Plus System (PerkinElmer Life and Analytical Sciences).

Plasmid construction and transfection of cultured neurons. To make the RNA expression vector pSyn-MS2-MMP9UTR, we amplified human synapsin-1 promoter and cloned it to the pBluescript vector containing 24 copies of MS2-binding site RNA hairpin from pSL-MS2-12X (Addgene plasmid 27119) by the sequence and ligation-independent cloning (SLIC) method (Li and Elledge, 2007). The PCR primers were as follows: hsynF, 5'-aaggga acaaaagctggagctccaccgcggggatccgcggcccgggtcac- $3^{\prime}$; $\quad$ hsynR, $5^{\prime}$-aggcaattaggtaccttaggatccactagtcagcttgaattctcgactgc- $3^{\prime}$.

The resulting plasmid, pSyn24MS2, was used for cloning the rat MMP-9 coding sequence and 3'UTR. MMP-9 was amplified from cDNA obtained from kainic acid-stimulated rat brain. Cloning was performed using the SLIC method with PCR primers: MMP-9F, 5' -gtctgcagtattcccg ggttcattagatctatgaaccctggcagccctgctcc-3'; MMP-9R, 5' -tatcgataagctga gctctttattaagcttccgaggaagatacttgg- $3^{\prime}$.

The resulting construct was sequenced to confirm its integrity.

Cells were transfected using Lipofectamin (Invitrogen), according to the manufacturer's protocol, at 10 DIV with a plasmid carrying EGFP under the control of the $\beta$-actin promoter or cotransfected with pMS2GFP (Addgene plasmid 27121) and pSyn-MS2-MMP9UTR.

Image acquisition and processing. Neurons and brain slices were examined under a spectral confocal microscope (TCS SP5; Leica). The settings of photomultipliers were adjusted to obtain the maximal dynamic ranges of pixels in each channel. The number of MMP-9 mRNA-positive granules was counted per $50 \mu \mathrm{m}$ of dendrite in the minimum distance of 10 $\mu \mathrm{m}$ from the cell body. The analysis was performed in a stack of three confocal $Z$ sections of total $0.63 \mu \mathrm{m}$ thickness, acquired using a $100 \times$ objective (oil immersion; 1.4 NA) with a zoom factor of 2 . The data were recorded for 10 primary dendrites per each time point. Three independent experiments were performed for this quantification. For statistical analysis, the Student's $t$ test was used.

For live-cell analysis, we used TCS SP5 ( $100 \times$ objective, zoom factor 2; Leica), equipped with an environmental chamber. For time-lapse microscopy, three $z$-stacks were captured every $20 \mathrm{~s}$ for $5-10 \mathrm{~min}$. Movies were then assembled after projection of $z$-stacks using LAS AS software (Leica).

Western blotting. After the stimulations, neurons or synaptoneurosomes $(\mathrm{SNs})$ were lysed in the $1 \times$ SDS sample buffer, denatured, and fractionated on $12 \%$ SDS-polyacrylamide gels. The samples were electrotransferred onto PVDF membranes (Immobilon-P; Millipore), which were blocked $2 \mathrm{~h}$ at room temperature with $10 \%$ nonfat milk in PBST. After blocking, the membranes were incubated at $4{ }^{\circ} \mathrm{C}$ overnight with the following antibodies: antiPSD-95 (MAB1598, 1:5000; Millipore), anti-c-Jun (9165; Cell Signaling Technology), anti- $\beta$-dystroglycan (NCL-b-DG; Novocastra), anti-MMP-9 (2270; Cell Signaling Technology), anti-GFAP (sc-166458; Santa Cruz Biotechnology), anti-phospho Erk1/2 (9160; Cell Signaling Technology), antiArc (sc-17839; Santa Cruz Biotechnology), or anti-GAPDH (MAB374; Millipore); all were diluted in 5\% nonfat milk in PBST. Membranes were incubated $1 \mathrm{~h}$ at room temperature with a peroxidase-labeled secondary antibody in 5\% nonfat milk in PBST and visualized with ECLplus reagent (GE Healthcare).

Preparation of synaptoneurosomes. Synaptoneurosomes were prepared from postnatal day 26 (P26) rats in a similar way as described previously (Hollingsworth et al., 1985; Scheetz et al., 2000). Briefly, cortex and hippocampi from one rat were dissected and homogenized on ice in $1 \mathrm{ml}$ of homogenization buffer (in mM: $125 \mathrm{NaCl}, 1.2 \mathrm{MgSO}_{4} 2.5 \mathrm{CaCl}_{2}, 1.53$ $\mathrm{KH}_{2} \mathrm{PO}_{4}, 212.7$ glucose, $4 \mathrm{NaHCO}_{3}, \mathrm{pH} 7.4$, set with carbogen), supplemented with Protease Inhibitor Cocktail (Sigma-Aldrich) and $100 \mathrm{U} / \mathrm{ml}$ mammalian placental RNase inhibitor (Fermentas). The final volume of the homogenate was set at $8 \mathrm{ml}$ per one brain with homogenization buffer, and the samples were passed through a series of nylon mesh filters consecutively (100,60,30, and $10 \mu \mathrm{m}$; Millipore) and centrifuged at $1000 \times g$ for $15 \mathrm{~min}$. The pellets containing synaptoneurosome preparations were washed once in the same volume of homogenization buffer, centrifuged as before, and resuspended in homogenization buffer to a final protein concentration of $1 \mathrm{mg} / \mathrm{ml}$. Protein concentration was measured using the BCA protein assay (Pierce Chemical).

Polysome assay. Synaptoneurosomes prepared from the P26 rats were prewarmed at $37^{\circ} \mathrm{C}$ for $5 \mathrm{~min}$ and stimulated with a $30 \mathrm{~s}$ pulse of $10 \mu \mathrm{m}$ glutamate and $50 \mu \mathrm{M}$ NMDA (Scheetz et al., 2000) for $15 \mathrm{~min}$ at $37^{\circ} \mathrm{C}$. Next, synaptoneurosomes were lysed in $1 \mathrm{ml}$ of lysis buffer $[20 \mathrm{~mm}$ Tris-HCl, $\mathrm{pH}$ 7.4, $125 \mathrm{~mm} \mathrm{NaCl}, 5 \mathrm{~mm} \mathrm{MgCl}, 1,5 \%$ Triton X-100, protease inhibitor without EDTA (Sigma-Aldrich), and $120 \mathrm{U} / \mathrm{ml}$ RiboLock (Fermentas)]. Membranous structures were removed by spinning at 20,000 $\times g$ for $40 \mathrm{~min}$. The resulting supernatant was loaded on a $10-50 \%$ linear sucrose gradient (prepared in $20 \mathrm{~mm}$ Tris- $\mathrm{HCl}$, pH 7.5, $125 \mathrm{~mm} \mathrm{NaCl}$, and $5 \mathrm{~mm} \mathrm{MgCl}_{2}$ ) and spun at 38,000 rpm for $2 \mathrm{~h}$ in a SW41 rotor (Beckman Coulter). Each gradient was separated into 10 fractions, $1 \mathrm{ml}$ each.

$R N A$ isolation from polysomal fractions and radioactive quantitative PCR. Each fraction was supplemented with 1:10 vol of $3 \mathrm{~m}$ sodium acetate, $\mathrm{pH}$ 5.2; 

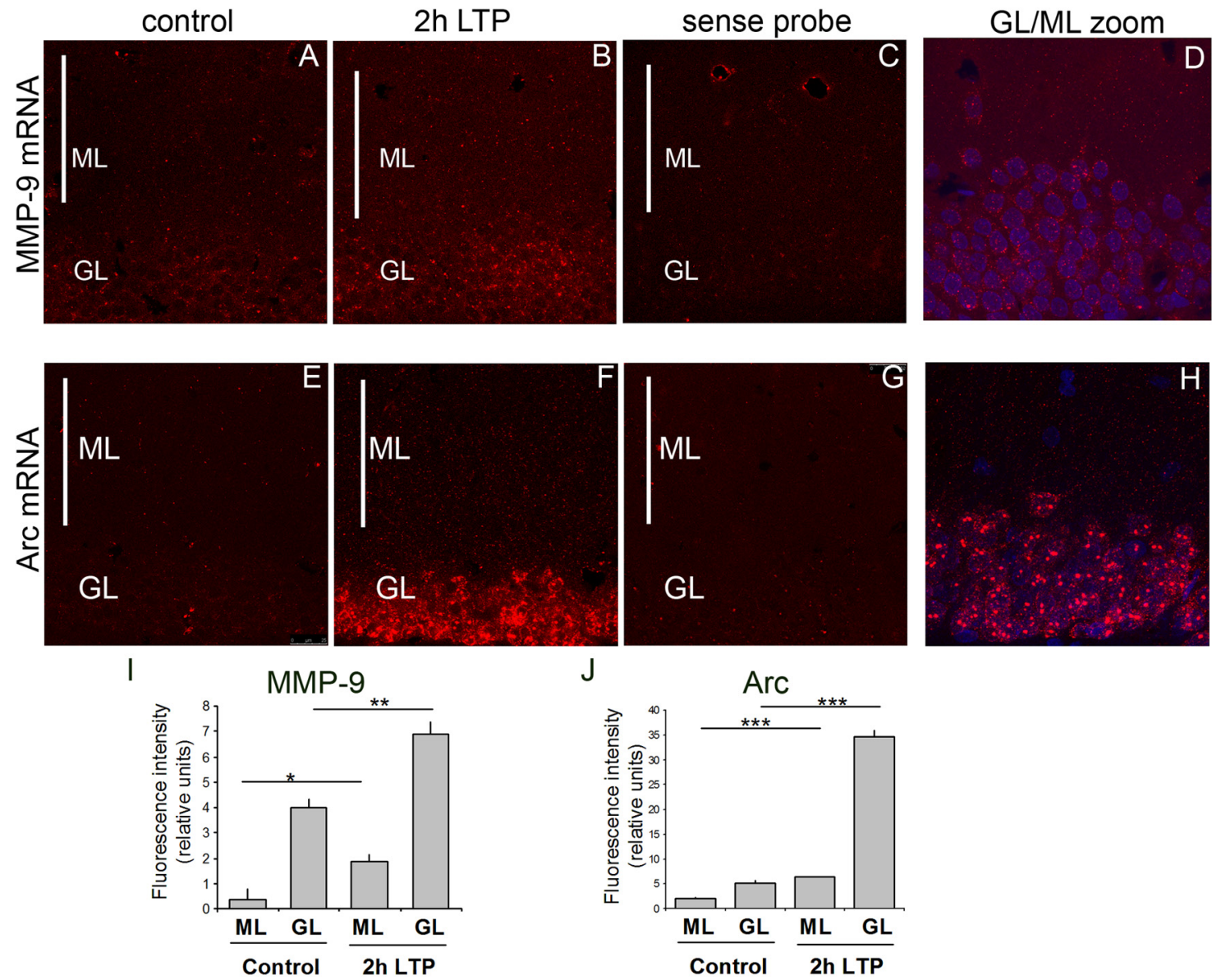

Figure 1. Localization of MMP-9 and Arc mRNA by fluorescent in situ hybridization in the granule and molecular layers of dentate gyrus. $A, B, E, F$, Representative staining of dentate gyrus coronal sections from control brain $(\boldsymbol{A}, \boldsymbol{E})$ or $2 \mathrm{~h}$ after high-frequency stimulation leading to $L T P(\boldsymbol{B}, \boldsymbol{F}) . \boldsymbol{C}, \boldsymbol{G}$, The sense probes showed uniform background levels on the section. $\boldsymbol{D}, \boldsymbol{H}$, Higher magnification of the border region between dentate gyrus molecular and granule cell layers to visualize granule cells extending dendrites into the molecular layer. $I, J$, Fluorescence intensity was measured with Fiji software in molecular and granule cell layers on three slices from three HFS-stimulated animals and three controls. The sense probe was quantified for molecular and granule cell layers and subtracted as a background from the intensity of fluorescence measured for molecular and granule cell layers antisense probes. MMP-9 and Arc mRNA was upregulated in the molecular and granule cell layers $2 \mathrm{~h}$ after HFS compared with unstimulated controls. ${ }^{*} p<0.05 ;{ }^{* *} p<0.01 ;{ }^{* * *} p<0.005$, unpaired $t$ test. $n=3$ animals per group. The graph represents mean values \pm SEM. GL, Granule cell layer; ML, molecular layer.

$10 \mu \mathrm{g}$ of tRNA (from Escherichia coli; Sigma-Aldrich); glycogen (Fermentas) as a precipitation enhancer; and $100 \mathrm{ng}$ of in vitro transcribed 400nucleotide-long fragment of Arabidopsis thalinana LSM gene as a spike control. RNA was precipitated with 1 vol of isopropanol at $-80^{\circ} \mathrm{C}$ overnight. After centrifugation, resulting pellets were dissolved in proteinase $\mathrm{K}$ digestion buffer $(0.5 \%$ SDS, 1 mм EDTA, $20 \mathrm{~mm}$ Tris- $\mathrm{HCl})$, and proteinase $\mathrm{K}$ was added to the final concentration of $100 \mu \mathrm{g} / \mathrm{ml}$ for a $20 \mathrm{~min}$ incubation at $42^{\circ} \mathrm{C}$. Next, RNA was extracted with a phenol/chloroform/izoamyl alcohol (25:24:1) solution (Sigma-Aldrich), precipitated with 2.5 vol of ethanol, centrifuged, washed twice in $70 \%$ ethanol and once in $90 \%$ ethanol, air dried for $10 \mathrm{~min}$, and dissolved in $30 \mu \mathrm{l}$ of RNase-free double-distilled water. Concentration and quality of extracted RNA was analyzed on Nanodrop and by agarose gel electrophoresis.

RNA samples were DNase treated, and an equal volume from each fraction ( $10 \mu \mathrm{l}$ containing an average amount of $3 \mu \mathrm{g}$ of total RNA) was reverse transcribed using SuperScript III reverse transcriptase (Invitrogen) with 200 ng of random hexamer (Fermentas). An aliquot of reverse transcription (RT) reaction was PCR amplified with TaqDNA polymerase (Invitrogen) in a final volume of $20 \mu \mathrm{l}$ using $10 \mathrm{pmol}$ of each primer plus $2.5 \mathrm{pmol}$ of $\left[\gamma_{-}{ }^{32} \mathrm{P}\right]$-ATP-labeled forward primer. The sequences of used primers were as follows: MMP-9 forward, $5^{\prime}$-taaaggtcgctcggatgg- $3^{\prime}$; MMP-9 reverse, $5^{\prime}$-ta ctgcttgcccaggaagac-3'; LSM spike forward, $5^{\prime}$-tcttctctctccgtgtcca- $3^{\prime}$; LSM spike reverse, $5^{\prime}$-tgatcaattcgccaatgcg-3'; Arc forward, $5^{\prime}$-ccgaagtgtccaagcagg tg-3'; Arc reverse, $5^{\prime}$-ccgtccaagttgttctccag-3'.

$D Q$ gelatin assay on synaptoneurosomes. Synaptoneurosomes were isolated from 3- to 4-week-old rats in the presence of $100 \mathrm{~mm} \mathrm{APV}$, washed once, and resuspended in the synaptoneurosome isolation buffer without APV at a $1 \mathrm{mg} / \mathrm{ml}$ protein concentration. Next, they were incubated for $10 \mathrm{~min}$ in $37^{\circ} \mathrm{C}$. After the incubation, synaptoneurosomes were stimulated with $50 \mu \mathrm{M}$ NMDA and $10 \mu \mathrm{M}$ glutamate. Stimulation was terminated with $100 \mathrm{~mm}$ APV after $1 \mathrm{~min}$, and they were incubated for 5 or 15 $\min$ at $37^{\circ} \mathrm{C}$. Then, synaptoneurosomes were centrifuged at $12,000 \times \mathrm{g}$, $15 \mathrm{~min}$; and the supernatants, containing secreted proteins, were collected for DQ gelatin zymography. Fluorescence was measured on the microplates. The sample contained $20 \mu \mathrm{l}$ of dye-quenched gelatin (DQ gelatin from pig skin, fluorescein conjugate; Invitrogen) and $20 \mu \mathrm{l}$ of the supernatant each, diluted in the sample buffer provided by the manufacturer. Microplates were incubated in $37^{\circ} \mathrm{C}$ for $3 \mathrm{~h}$ and measured on microplate reader Infinite F200 (Tecan).

PCRpoly (A) testassay. RNAwas extracted from unstimulated orglutamatestimulated $(100 \mu \mathrm{M})$ synaptoneurosomes with Trizol (Invitrogen). An oligonucleotide anchor (adapter primer) was ligated to the $3^{\prime}$ end of the isolated mRNA population. The adapter primer sequence was $5^{\prime}$ gtgagatcatgcacagtcata-[AmC7]. After reverse transcription with an antiadapter reverse primer, two series of nested PCR with a reverse primer complementary to the ligated anchor and a specific forward primer for MMP-9 located upstream of the AAUAAA (PolyA III) polyadenylation signals were performed. PCR products were analyzed on 2\% agarose gels (Metaphor). The sequence of primers used were as follows: MMP-9UTRexternal, $5^{\prime}$-ctcacaggggaaacag-3'; MMP-9UTRinternal, 5' -agatgatccctcagtg- $3^{\prime}$.

Detection of newly synthesized proteins with Click iT. Freshly isolated synaptoneurosomes were incubated with L-homopropargylglycine (HPG), an 


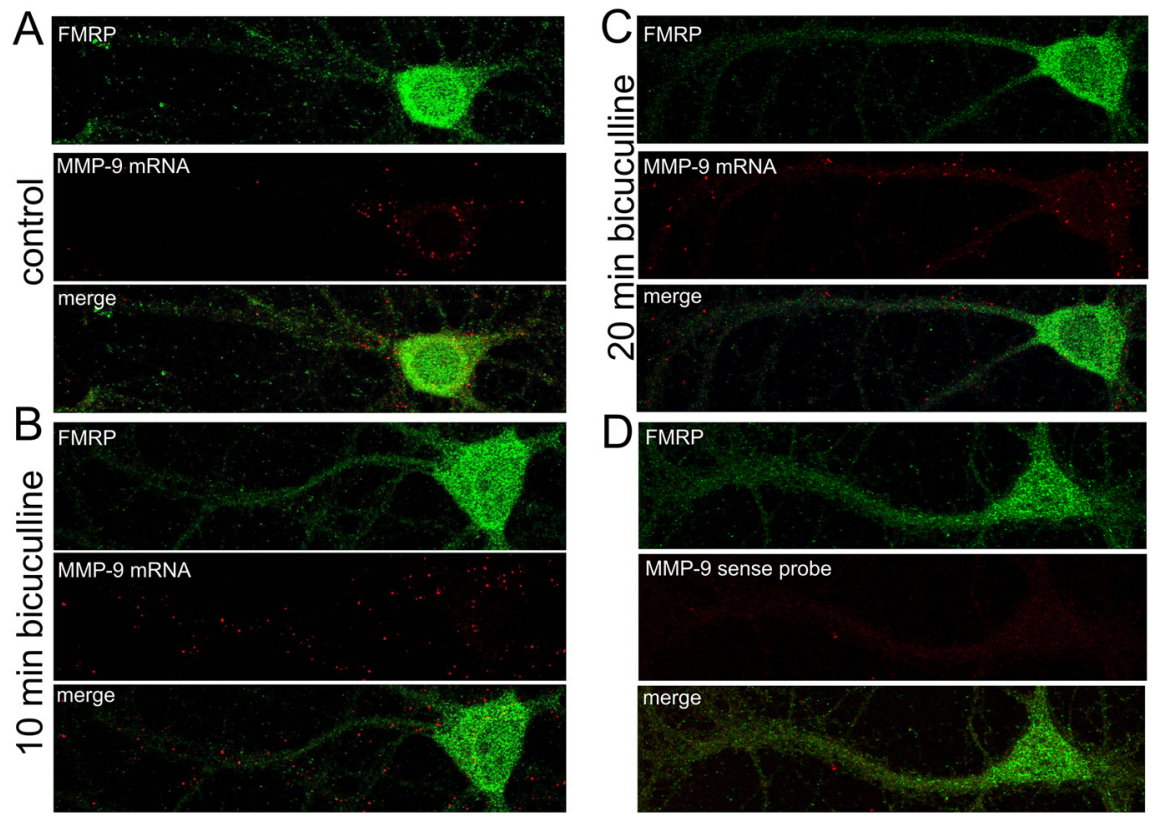

E

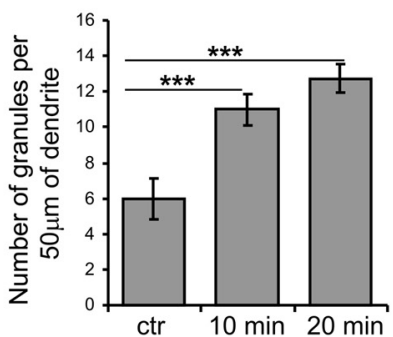

Figure 2. Dendritic transport of MMP-9 mRNA is regulated by synaptic stimulation in hippocampal neurons. Fluorescent in situ hybridization combined with immunofluorescence shows MMP-9 mRNA granules in dendrites stained with anti-FMRP antibody. $\boldsymbol{A}$, For the control and before bicuculline application the cells were incubated for $3 \mathrm{~h}$ with inhibitors. $\boldsymbol{B}, \boldsymbol{C}$, To activate synaptic release of glutamate, cultured hippocampal neurons were stimulated by application of bicuculline for $10 \min (\boldsymbol{B})$ or $20 \mathrm{~min}(\boldsymbol{C})$. D In situ hybridization with the sense probe. $\boldsymbol{E}$, The number of MMP-9-positive mRNA granules was counted per $50 \mu \mathrm{m}$ of dendrite 10 neurons for each experimental condition $(n=10)$. Similar results were obtained in three independent experiments. ${ }^{* * *} p<$ 0.001 , Mann-Whitney test. The graph represents mean values \pm SEM. ctr, Control.

amino acid analog that contains a small modification, an alkyne moiety that can interact with azide moiety in "click" reaction. After 15 min preincubation with HPG, synaptoneurosomes were stimulated with $100 \mu \mathrm{M}$ glutamate for $5 \mathrm{~min}$ at $37^{\circ} \mathrm{C}$. Ten minutes before stimulation and during glutamate treatment, half of the synaptoneurosomes were additionally incubated with a protein synthesis inhibitor, anisomycin $(20 \mu \mathrm{M})$. The controls were incubated only with HPG. After the stimulation, synaptoneurosomes were resuspended in lysis buffer ( $50 \mathrm{~mm}$ Tris- $\mathrm{HCl}, \mathrm{pH}$ 8.0, and 0,5\% SDS), and the click reaction with biotin-azide (Invitrogen) was performed accordingly to the manufacturer's protocol (Invitrogen). Proteins were precipitated with methanol, and the pellets were dissolved in $100 \mu$ l of buffer- 1 ( $8 \mathrm{M}$ urea, 100 $\mathrm{mm}$ Tris- $\mathrm{HCl}, \mathrm{pH} 8.0$, and $200 \mathrm{~mm} \mathrm{NaCl}$ ). HPG-biotin-stained proteins were enriched on streptavidin dynabeads (MyOne; Invitrogen) preequilibrated in buffer-1. After a $1 \mathrm{~h}$ incubation at room temperature, the streptavidin beads were washed three times in $1 \mathrm{ml}$ of buffer- 1 and three times in $1 \mathrm{ml}$ of buffer- 1 with $2 \%$ SDS. The proteins were eluted by incubation in a $1 \times$ sample buffer containing $2.5 \mathrm{~mm}$ biotin for $15 \mathrm{~min}$ at $96^{\circ} \mathrm{C}$. Western blot with anti-MMP-9 antibody (2270; Cell Signaling Technology) or anti-Arc (sc-17839; Santa Cruz Biotechnology) was performed to detect precipitated proteins.

\section{Results}

MMP-9 mRNA translocates to the molecular layer of DG $2 \mathrm{~h}$ after LTP induction

Previous studies indicated that seizures induced by kainic acid led to the induction of MMP-9 mRNA transcription in the rat hip- pocampus and dentate gyrus and to MMP-9 mRNA redistribution to the molecular layer of the dentate gyrus (Szklarczyk et al., 2002; Konopacki et al., 2007). Here, we asked whether induction of LTP, a well established model of synaptic plasticity, similarly affects MMP-9 mRNA expression. LTP was induced by brief bursts of HFS applied to the medial perforantpath input to the dentate gyrus of rats. Two hours after the LTP induction, the brains were sectioned and subjected to the fluorescent in situ hybridization using a cRNA probe covering the MMP-9 coding sequence and its 3' UTR. Fluorescence intensity was measured in the granule cell body and molecular layer of the dentate gyrus. Granule cell dendrites extend into the molecular layer and receive input from the perforant path. We observed an increase in the MMP-9 mRNA level in the granular layer of DG $2 \mathrm{~h}$ after the LTP induction and enhanced expression of mRNA across the molecular layer of the dorsal dentate gyrus (Fig. $1 A-D$ ). Densitometric analysis of single-stack confocal images revealed a 3.5-fold increase in fluorescence intensity in the granule cell body layer and a fourfold increase in the molecular layer in the HFS-treated dentate gyrus compared with contralateral control (Fig. 1I). In situ hybridization for Arc was a positive control as Arc mRNA is rapidly induced and transported to granule cell dendrites under the same conditions of LTP induction (Messaoudi et al., 2007; Panja et al., 2009). As expected, Arc mRNA showed a broad somatodendritic pattern of expression after LTP stimulation (Fig. $1 E--H$ ). The overall intensity of the signal detected by the Arc probe was much stronger than for the MMP-9 probe; therefore, different microscope settings were applied to visualize these two probes. The intensity of fluorescence quantified for Arc was increased sevenfold in the granule cell body layer and threefold in the molecular layer (Fig. $1 \mathrm{~J}$ ) as a result of LTP. Moreover, the main difference in the expression pattern of these two mRNAs was in the mode of their activation. Arc displayed the pattern of activation characteristic for immediate-early genes; MMP-9 mRNA, on the other hand, was constitutively expressed in the brain and stimulated by LTP (its expression and translocation to the dendrites). As a negative control, the sense MMP-9 and Arc probes were used, did not reveal any signal, and only showed uniform background levels on the section (Fig. 1C,G).

\section{Activity-dependent dendritic transport and synaptic} localization of MMP-9 mRNA in hippocampal neurons Dendritically localized mRNAs are transported in large ribonucleoprotein particles (RNPs), which have been referred to as RNA granules. Therefore, we examined MMP-9 mRNA transport in the hippocampal neurons in culture after synaptic stimulation. Toward this end, we applied bicuculline, a blocker of $\mathrm{GABA}_{\mathrm{A}}$ receptors that removes inhibitory action of GABA and thus in- 

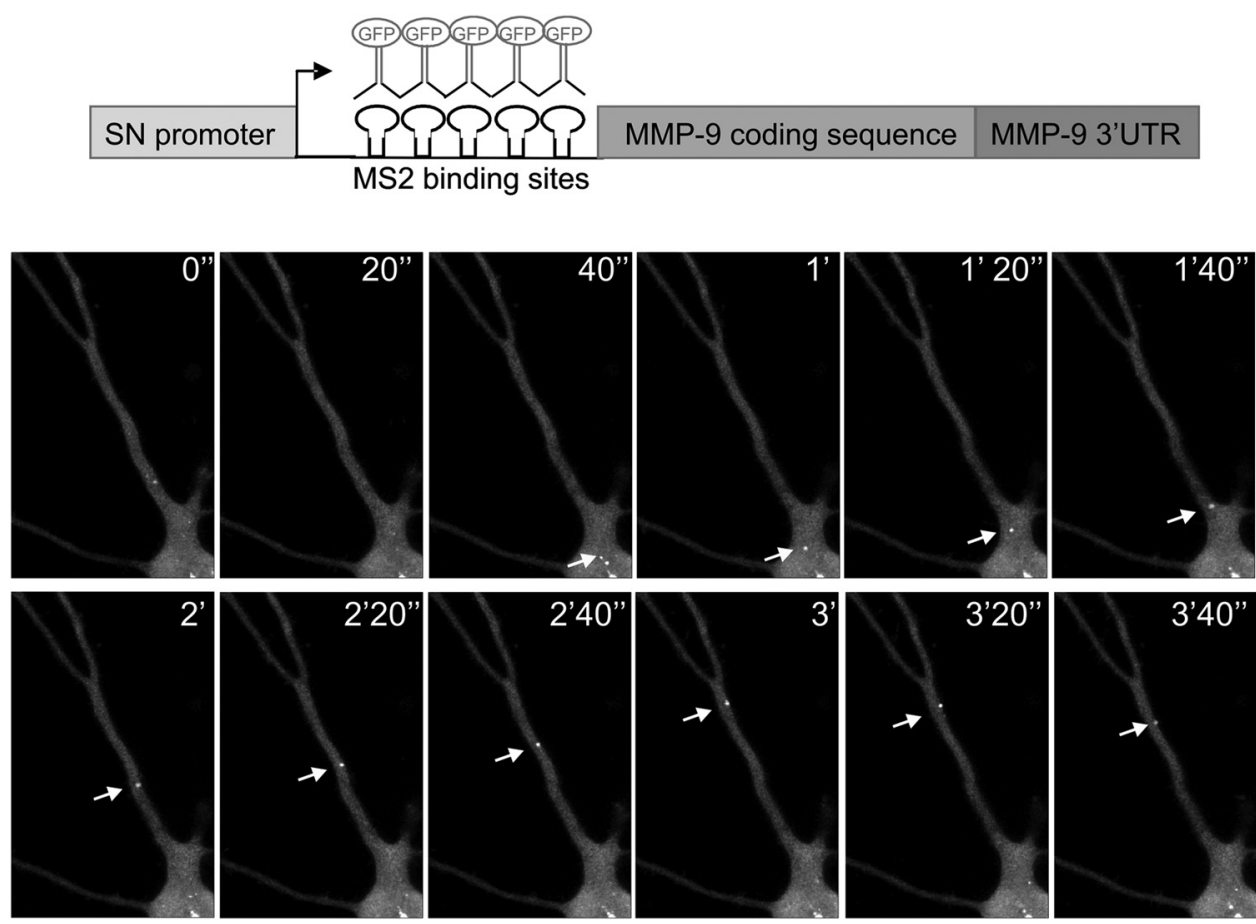

Figure 3. MMP-9 mRNA-containing granules show direct movement along dendrites of rat hippocampal neurons. Hippocampal neurons were cotransfected with two vectors, pSyn-MS2MMP9UTR vector containing the MMP-9 coding sequence with the 3'UTR and 24 copies of MS2-binding site RNA hairpin, under the control of synapsin-1 promoter; and pMS2-GFP vector expressing MS2-binding protein as a fusion with GFP and nuclear localization sequence. After expression of both constructs, the GFP fusion should bind as a dimer to each MS2-binding site of the RNA construct (top). GFP-labeled MMP-9 mRNA observed in the living cell by time-lapse microscopy shows many small granules in the dendrites. Sequential images were taken every $20 \mathrm{~s}$; the arrow shows one granule moving bidirectionally along the dendrite.

duces an increase in the glutamate-driven activity of the neuronal network. First, the cells were incubated with a mixture of TTX, CNQX, APV, and nifedipine for $3 \mathrm{~h}$ to silence the neuronal activity. After washing out APV, bicuculline was applied to the cells for 10 and $20 \mathrm{~min}$. In this stimulation protocol (synaptic protocol), only the synaptic pool of NMDA receptors is activated (Ivanov et al., 2006). The cells were fixed and subjected to in situ hybridization with the cRNA probe containing the coding sequence and 3'UTR of the MMP-9 transcript and sense probe as a negative control (Fig. 2D). In addition, the cells were immunostained with an antibody against FMRP, a protein abundant in neuronal cell body and dendrites. In control cultures, kept quiescent for $3 \mathrm{~h}$, MMP-9 mRNA was mainly present in the cell soma (Fig. 2A). In contrast, application of bicuculline induced mRNA transport to the dendrites (Fig. 2B,C). Subsequently, MMP-9positive mRNA granules were counted per $50 \mu \mathrm{m}$ of dendrite, and there was a significant increase in MMP-9 mRNA granule number at 10 and $20 \mathrm{~min}$ after the stimulation (Fig. 2E). Similar results were obtained using a digoxigenin RNA-labeled probe (data not shown).

Next, we used the MS2 bacteriophage tagging system to directly visualize movement of MMP-9 mRNA-containing granules in cultured hippocampal neurons. The MMP-9 coding sequence with the $3^{\prime}$ UTR was cloned into the vector containing 24 copies of MS2-binding site RNA hairpin under the control of a neuronal-specific promoter, Synapsin-1 (pSyn-MS2MMP9UTR) (Fig. 3, top). This construct was cotransfected with the plasmid pMS2-GFP, expressing MS2-binding protein as a fusion with EGFP and nuclear localization sequence (NLS). Expression of both plasmids in the cell enables binding of the GFP fusion protein to the MS2-tagged MMP-9 mRNA, allowing timelapse videomicroscopy of GFP-labeled MMP-9 mRNA particles.

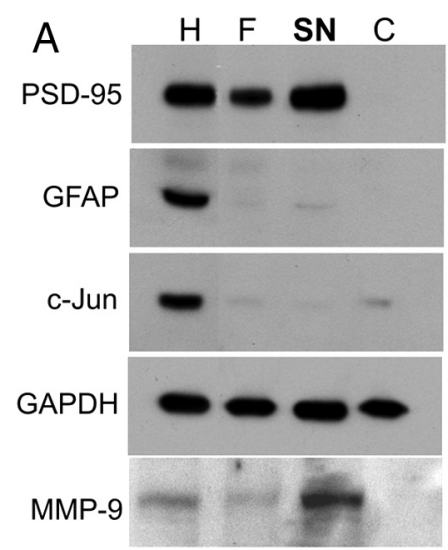

B
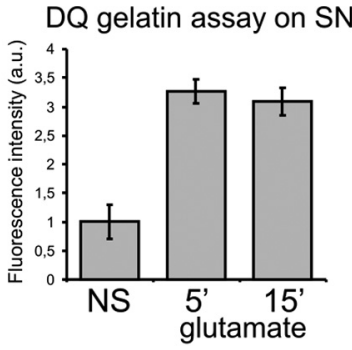

Figure 4. MMP-9 protein is enriched in the synaptoneurosomal fraction. $\boldsymbol{A}$, Characterization of protein content of the synaptoneurosomal fraction. Crude homogenate $(H)$, filtrate $(F)$, SNs, and supernatant [cytosolic (C)] fractions were analyzed by Western blot to determine the distribution pattern of synaptic and nonsynaptic proteins. Synaptic protein PSD-95 and MMP-9 were enriched in the SN. The glial protein GFAP and the nuclear protein c-Jun were either diminished or absent in the SN fraction. $\boldsymbol{B}$, The activity of MMP-9 released by NS or enhanced in stimulated ( $10 \mu \mathrm{m}$ glutamate, $50 \mu \mathrm{m}$ NMDA for 5 or $15 \mathrm{~min}$ ) synaptoneurosomes, as measured by the $\mathrm{DQ}$ gelatin assay. Error bars represent $S D ; n=3$.

Observed granules were either stationary or moving bidirectionally along the dendrite (Fig. 3, bottom). As a control, cells were transfected with the pMS2-GFP construct and showed uniform diffuse staining.

\section{Synaptically regulated MMP-9 protein synthesis}

To determine whether dendritically targeted MMP-9 mRNA is effectively translated at synapses, we have used a synaptoneurosomal 
A

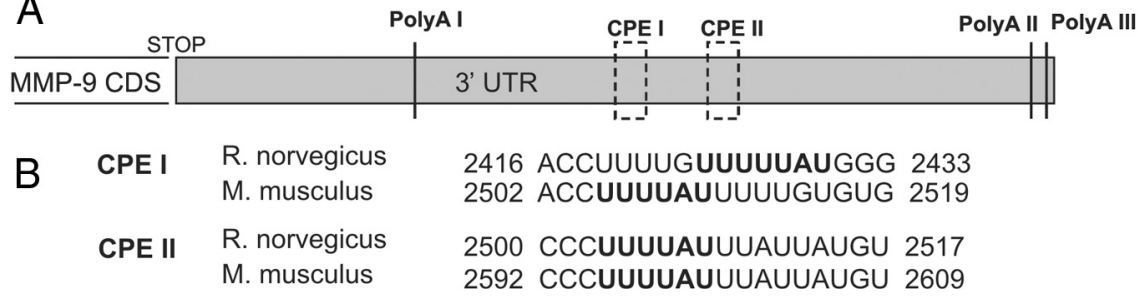

C

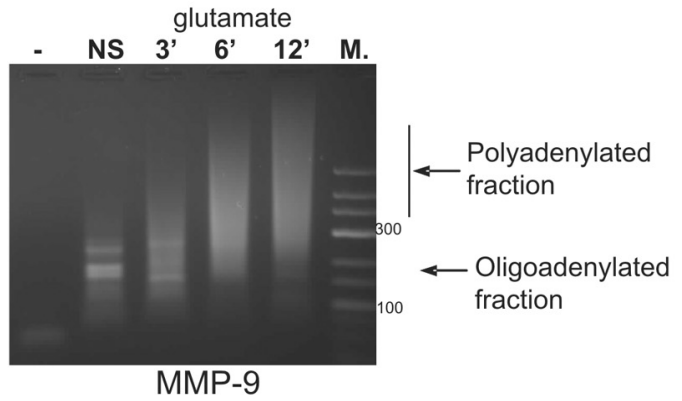

E

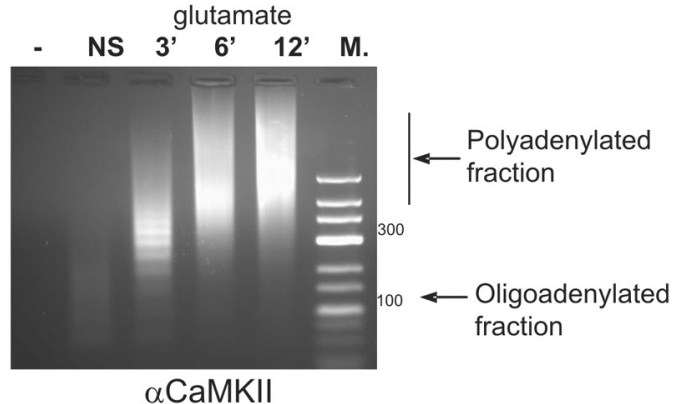

F

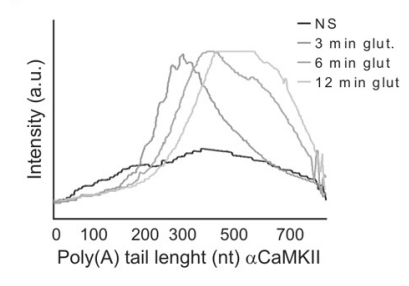

Figure 5. MMP-9 mRNA is rapidly polyadenylated in synaptoneurosomes after glutamate stimulation. $\boldsymbol{A}$, Schematic representation of the rat MMP-9 3'UTR structure with putative poly(A) sites and (PEB binding sites. $\boldsymbol{B}$, Alignment between the MMP-9 3'UTR regions from rat and mouse containing CPEB binding sites. Consensus sequences are bolded. C, E, MMP-9 and $\alpha$ CaMKII mRNA polyadenylation measured by PAT assay. Synaptoneurosomes were either NS or stimulated with glutamate for 3, 6, or 12 min. M, Size marker. Oligoadenylated and polyadenylated forms of MMP-9 and $\alpha$ CaMKII mRNAs are indicated by black arrows. $D$, $\boldsymbol{F}$, Dispersion graph representing the distribution of the MMP-9 and $\alpha$ CaMKII polyadenylated transcripts in NS (black line) and glutamate-stimulated (3,6, and 12 min; gray lines) SN. The signal intensity along the lane has been plotted against the poly $(A)$ tail length, estimated from the molecular markers loaded on the same gel.

preparation that consists of pinched-off and resealed presynaptic terminals attached to resealed postsynaptic processes. Synaptoneurosomes (SNs) isolated from the brain retain normal functions of neurotransmitter release, receptor activation, and various postsynaptic responses including activity-dependent protein synthesis (Greenough et al., 2001). The details on isolation of synaptoneurosomes from the rat hippocampus and cerebral cortex and their validation are described in Materials and Methods as well as in Figure 4A. Enrichment in synaptic proteins such as PSD-95 in the SN fraction was confirmed, whereas glia-expressed GFAP or nuclear c-Jun were deprived from SN preparations (Fig. 4A). Consistent with the in situ hybridization analysis of MMP-9 mRNA localization at the synapse, MMP-9 mRNA was detected in the synaptoneurosomes with RT-PCR (data not shown). To check whether MMP-9 can be released by SN after stimulation, we measured the activity of MMP-9 in the supernatant obtained by centrifugation of nonstimulated (NS) or glutamate-stimulated (10 $\mu \mathrm{M}$ glutamate and $50 \mu \mathrm{M}$ NMDA for 5 or $15 \mathrm{~min}$ ) synaptoneurosomes. The assay we used (EnzChek Gelatinase/Collagenase Assay kit) was chosen because of its high sensitivity to measure gelatinase activity. The experiment revealed an increase in MMP-9 activity in the supernatant of stimulated synaptoneurosomes (Fig. 4B).
mRNA polyadenylation has been shown to enhance translation of several dendritically localized mRNAs (Bramham and Wells, 2007; Richter, 2010). We noted the presence of three polyadenylation sites (AAUAAA) and two consensus binding sites for cytoplasmic polyadenylation element-binding protein (CPEB) located at the -297 and -375 nucleotides of MMP-9 3' UTR (Fig. 5A). Both sites are evolutionary conserved between rat and mouse in the MMP-9 3'UTR sequence (Fig. 5B). Thus, we applied the PCR poly(A) test (PAT) assay to assess the polyadenylation status of MMP-9 mRNA in control and stimulated synaptoneurosomes. $\alpha$ CaMKII was used as a positive control. Synaptoneurosomes freshly isolated from rat brain were incubated with glutamate for 3, 6, and $12 \mathrm{~min}$ at $37^{\circ} \mathrm{C}$. Immediately after the stimulation, RNA was extracted with Trizol reagent, and the PAT assay was performed. As shown in Figure 5, $C--E$, elongation of the poly(A) tail of MMP-9 and $\alpha$ CaMKII transcripts was evident after glutamate stimulation of the synaptoneurosomes.

In mammalian neurons, polyribosomes are found not only in the cell body but also in dendritic shafts and spines, where local translation may occur. To directly assess synaptic translation of MMP-9 mRNA, we examined its association with polysomal fractions isolated from stimulated synaptoneurosomes. The NMDARs are the key glutamate receptors involved in the regulation of multiple processes related to synaptic plasticity. To stimulate NMDA receptors on the isolated synaptoneurosomes, we used a $30 \mathrm{~s}$ pulse of $10 \mu \mathrm{M}$ glutamate and $50 \mu \mathrm{M}$ NMDA, referred to as NMDAR stimulation (Scheetz et al., 2000). NMDAR stimulation was terminated by the addition of APV and incubation for $15 \mathrm{~min}$ at $37^{\circ} \mathrm{C}$. Control synaptoneurosomes were incubated in APV for 5 min before NMDAR stimulation. After the lysis, the synaptoneurosome extract was separated by ultracentrifugation on a linear sucrose gradient (Fig. 6A). Ten fractions were collected from each gradient while recording the absorbance profile (Fig. 6B). An equal amount of synthetic RNA (U6 snRNA-associated Smlike protein-LSM from A. thaliana) was added to each fraction before RNA extraction for normalization. Total RNA was extracted from the gradient fractions and analyzed by quantitative, radioactive RT-PCR. Collected fractions were divided into five groups, which correspond to (from the top to the bottom of the gradient) free messenger ribonucleoprotein (mRNP) complexes; monosomal fraction; light polysomes; heavy polysomes, corresponding to the actively translating polyribosomal fraction; and RNA granules, the heavy fraction that sediments below the polysomes and contains RNA granules, as described by Krichevsky and Kosik (2001). We have observed association of MMP-9 and Arc mRNAs with polyribosomal fractions of unstimulated or stimulated synaptoneurosomes (Fig. 6C). SN stimulation leads to significantly increased association of MMP-9 and 
Arc mRNAs with polyribosomes (Fig. $6 D)$. The percentage of mRNA associated with polysomal fractions 3 and 4 (light and heavy polyribosomes) increased after the stimulation from $\sim 40$ to $48 \%$ for Arc and from 50 to $62 \%$ for MMP-9.

These changes correlated with different UV absorbance profiles for unstimulated and stimulated SN. We observed higher absorbance for the fraction representing monosomes and lower absorbance for fractions representing heavy polyribosomes in unstimulated SN. After the $\mathrm{SN}$ stimulation, the absorbance profile was lower for monosomes and higher for heavy polyribosomes (Fig. $6 B$ ).

To detect nascent MMP-9 protein synthesis, we applied the click chemistry system. Freshly isolated synaptoneurosomes were incubated with the amino acid ana$\log$ HPG, which is incorporated into the newly synthesized proteins. To stimulate protein synthesis, synaptoneurosomes were treated with $10 \mu \mathrm{M}$ glutamate and 50 $\mu \mathrm{M}$ NMDA. Anisomycin was added before the stimulation to inhibit activityinduced protein synthesis. The click-it reaction was conducted on $\mathrm{SN}$ protein extracts to obtain HPG-biotin-tagged proteins that were next enriched on streptavidin dynabeads. Isolated proteins were analyzed by Western blot with either anti-MMP-9 or anti-Arc antibody (as a positive control). As a result, both proteins were detected in the stimulated synaptoneurosomes (Fig. 6E,F). For MMP-9, two bands can be observed, with the top representing inactive pro-MMP-9 and the bottom representing an active form of MMP-9, actMMP-9 (Fig. 6E).
A

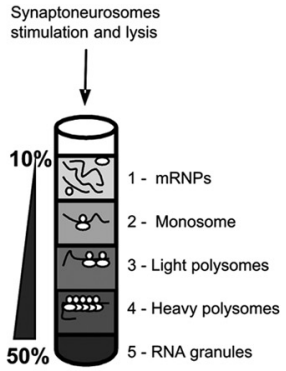

B

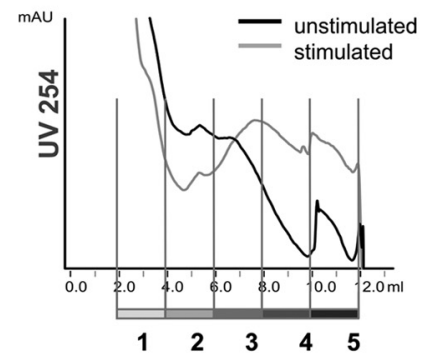

C Radioactive RT-PCR: unstimulated (NS)

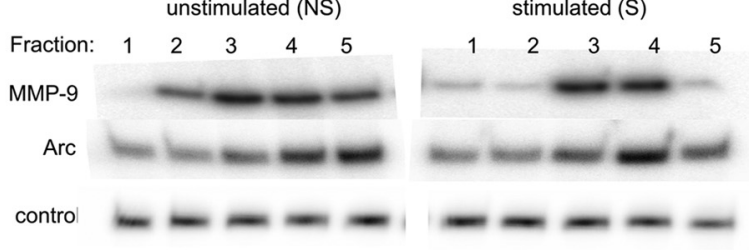

E

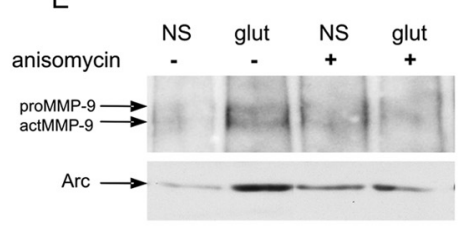

F

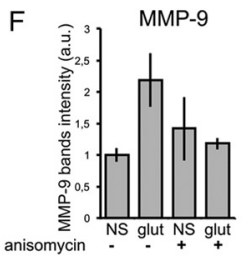

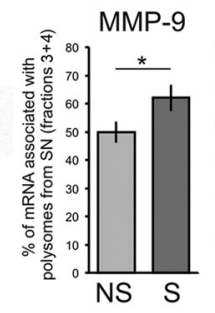
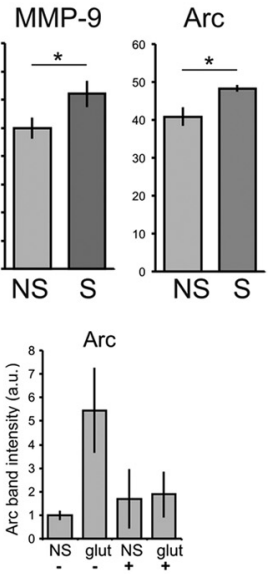

Figure 6. Polyribosome association and local translation of MMP-9 mRNAs in synaptoneurosomes. $\boldsymbol{A}$, The synaptoneurosomes were lysed; separated on a sucrose density gradient; and, according to the absorbance profile, divided into five fractions: free mRNP, monosomal fraction, light polysomes, heavy polysomes, and RNA granules. $\boldsymbol{B}$, A254 absorbance profiles from sucrose density gradients. C, Radioactive RT-PCR with primers specific for MMP-9, Arc, and control (LSM) mRNAs show polyribosome association of MMP-9 and Arc mRNAs in control (NS) and stimulated (10 $\mu \mathrm{m}$ glutamate, $50 \mu \mathrm{m}$ NMDA, 15 min) synaptoneurosomes. D, Polysomal incorporation of MMP-9 and Arc mRNAs is expressed as a percentage of mRNA in fractions 3 and 4 (polysomes). Synaptoneurosomal stimulation leads to increased association of MMP- 9 and Arc mRNAs with polyribosomes. ${ }^{*} p<0.05$, unpaired $t$ test; $n=5$. The graph represents mean values \pm SEM. $\boldsymbol{E}$, Local synthesis of MMP-9 protein detected with click chemistry. The proteins newly synthesized in synaptoneurosomes incorporate HPG that, in click reaction, is tagged with biotin and enriched on streptavidin dynabeads. Western blot on precipitated proteins show induction of MMP-9 and Arc protein synthesis in synaptoneurosomes after the stimulation. Application of $20 \mu \mathrm{M}$ anisomycin inhibits local translation of MMP-9 and Arc proteins. $\boldsymbol{F}$, Quantification of MMP-9 and Arc bands intensity shows an increase of protein synthesis in SN after stimulation and its inhibition by anisomycin. Error bars represent SD; $n=3$. The results were not statistically significant. The bands were quantified by measuring their intensity in a Fiji program; the background subtraction was done separately for each lane. S, stimulated; NS, not stimulated.

\section{Activity-dependent MMP-9 release is regulated by polyadenylation}

MMP-9 is released in response to enhanced neuronal activity driven by glutamate in the brain and in cultured neurons. We stimulated cultured hippocampal neurons by application of bicuculline (the synaptic protocol described above) or by direct bath application of glutamate. It has been shown before that stimulation of neurons in culture leads to the rapid increase in MMP-9 activity, as measured by cleavage of its native substrate, $\beta$-dystroglycan ( $\beta$-DG) (Michaluk et al., 2007). The proteolytic cleavage of $43 \mathrm{kDa}$ full-length $\beta$-DG protein leads to the appearance of $30 \mathrm{kDa}$ product, readily detected by Western blot. Application of MMP-9 inhibitor I to the hippocampal cultures before stimulation (50 $\mu \mathrm{M}$ glutamate) abolished the appearance of $30 \mathrm{kDa} \beta$-DG band (Fig. 7A).

We then asked whether MMP-9 proteolytic activity can be reduced by the polyadenylation inhibitor cordycepin ( $3^{\prime}$ deoxyadenosine). Hippocampal neurons were preincubated with cordycepin 10 min before either bicuculline or glutamate stimulation. We have observed that glutamate-evoked increase in the level of the cleaved $\beta$-DG form was significantly reduced by the cordycepin pretreatment (Fig. $7 B-E$ ).

\section{Discussion}

In the present study, we provide evidence for MMP-9 mRNA dendritic transport and its local translation at the activated synapses. We have shown activity-dependent transport of MMP-9 mRNA to dentate granule cell dendrites after LTP induction in rats and translocation to the dendrites of cultured hippocampal neurons. We have also observed that in synaptoneurosomes, glutamate-induced signaling can stimulate MMP-9 mRNA polyadenylation, association with actively translating polyribosomes, and de novo MMP-9 protein synthesis. Furthermore, we demonstrate that an increase in MMP-9 activity observed shortly (5-10 min) after glutamate stimulation in cultured hippocampal neurons can be substantially reduced by the polyadenylation inhibitor.

Previously, Szklarczyk et al. (2002) showed that MMP-9 mRNA is upregulated in the molecular layer of dentate gyrus $24 \mathrm{~h}$ after kainic acid treatment. This finding suggested that MMP-9 mRNA can be translocated to the dendrites of granular DG cells in effect of excessive neuronal stimulation and in the context of an aberrant synaptic plasticity (Zagulska-Szymczak et al., 2001). Here, we demonstrate by the use of fluorescent in situ hybridiza- 


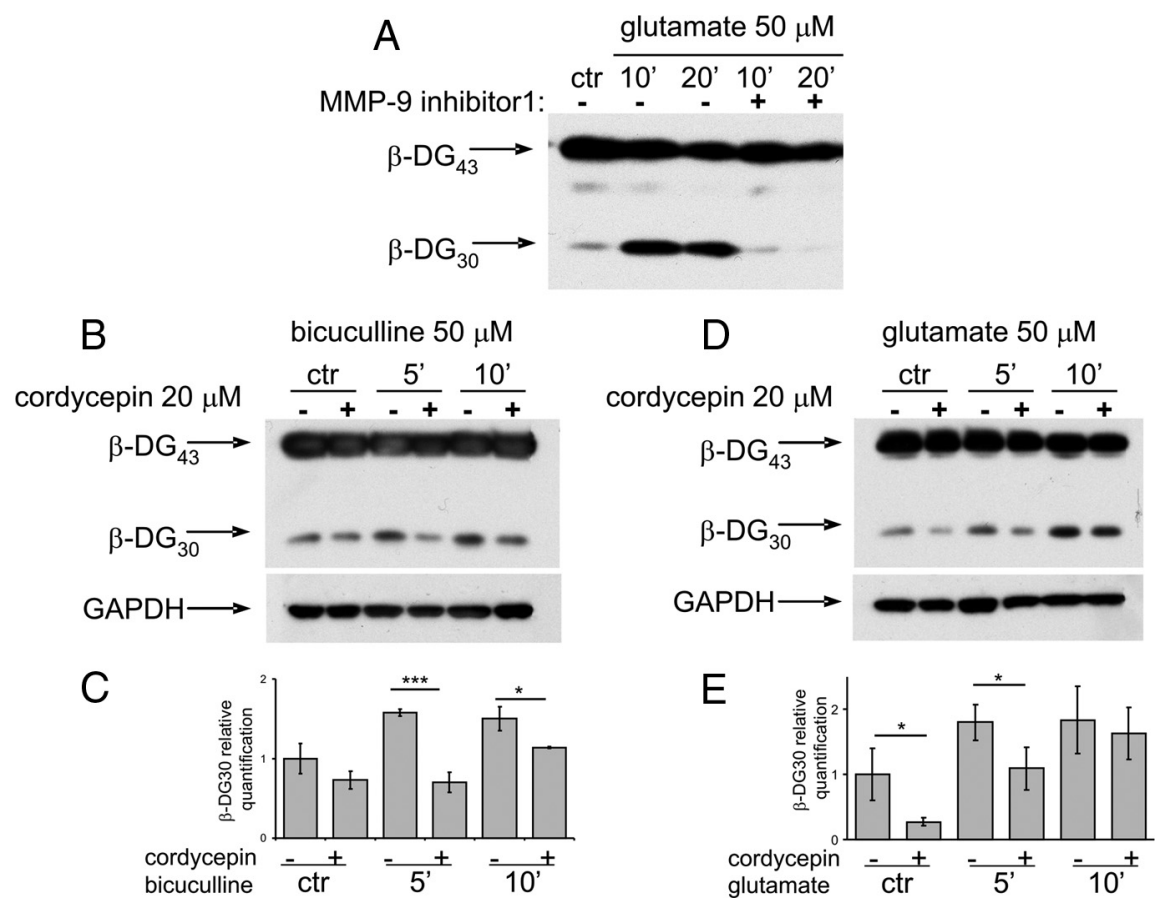

Figure 7. Glutamate-dependent increase in MMP-9 proteolytic activity is regulated by polyadenylation in cultured hippocampal neurons. $\boldsymbol{A}$, The effect of MMP-9 inhibitor I on activity-induced $\beta$-DG cleavage. Application of MMP-9 inhibitor I to the hippocampal neurons before glutamate stimulation results in reduction of $\beta$-DG cleavage. $\boldsymbol{B}, \boldsymbol{D}$, Representative Western blots of $\beta$-DG and GAPDH. Hippocampal neurons were preincubated with $20 \mu \mathrm{m}$ cordycepin $10 \mathrm{~min}$ before either bicuculline (synaptic protocol) or glutamate stimulation. GAPDH was a protein loading control. $\boldsymbol{C}, \boldsymbol{E}$, Quantification of $\beta$-DG 30 kDa product of MMP-9 cleavage intensity from three independent experiments $(n=3)$. ${ }^{*} p<0.05 ;{ }^{* *} p<0.01 ;{ }^{* *} p<0.001$, Mann-Whitney test. The graph represents mean values \pm SEM. ctr, Control.

tion that MMP-9 mRNA is more abundant in the dendrites of DG granule cells $2 \mathrm{~h}$ after LTP induced by HFS of the medial perforant path. This result indicates that MMP-9 mRNA is actively transported to the dendrites after the stimulation that results in synaptic plasticity. In the in situ hybridization experiment, we used Arc, an immediate-early gene whose expression is strongly activated $2 \mathrm{~h}$ after LTP stimulation, as a positive control (Panja et al., 2009). Unlike Arc, MMP-9 mRNA is constitutively expressed in the brain at very low levels, and LTP markedly stimulated its expression and translocation to the dendrites. The signal obtained for the MMP-9 mRNA probe in the in situ reaction was much weaker than the one obtained for Arc, thus confirming that MMP-9 was expressed at a lower level. In the recent study by Cajigas et al. (2012), the authors showed that the relative abundance of different mRNAs in the neuropil of CA1 fields in the hippocampus varies over 3 orders of magnitude. Among about 2,550 dendritic-axonal transcripts identified through deep sequencing in the synaptic neuropil, MMP-9 is listed with 8 reads and Arc with 33 reads in the coding sequence. These data suggest that Arc mRNA is about 4 times more abundant in the studied hippocampal region than MMP-9. We believe that the low level of MMP-9 expression in the brain is related to its protein function on the activated synapse. MMP-9 plays an important role in synaptic plasticity, but its overexpression was shown to be responsible for various pathological conditions such as epilepsy or stroke (Wilczynski et al., 2008; Rivera et al., 2010). This suggests that a high level of MMP-9 expression can be detrimental for the brain and needs to be tightly controlled.

An increased MMP-9 mRNA expression after LTP in vivo is delayed compared with rapid mRNA transport, synthesis, and release in the neuronal culture. This is apparently caused by the fact that what we observe within minutes in cultured neurons is occurring before the stimulated transcription of MMP-9 mRNA. In the brain, an increased MMP-9 gene expression (observed in the dentate gyrus $2 \mathrm{~h}$ after HFS stimulation) is a consequence of enhanced synaptic plasticity (Rivera et al., 2010). Therefore, the newly synthesized mRNA is transported along the dendrites to support increased demand on MMP-9 protein that has been secreted on the activated synapse during the first wave of synaptic response. Interestingly, Bozdagi et al. (2007) applied radioactive in situ hybridization to detect MMP-9 mRNA in hippocampus $75 \mathrm{~min}$ after LTP induction and observed no changes in MMP-9 mRNA levels or distribution with LTP. Several explanations could be offered to resolve this discrepancy. First, the timing might be critical. Rylski et al. (2008) reported increases in MMP-9 mRNA abundance in the hippocampus, starting from $2 \mathrm{~h}$ after enhanced neuronal activity evoked by the $\mathrm{GABA}_{\mathrm{A}}$ receptor antagonist pentylenetetrazole; hence, 75 min might be too early to observe accumulation of MMP-9 mRNA after LTP induction. Next, we have used a more sensitive fluorescent in situ hybridization method with a longer cRNA probe that spanned the coding sequence and 3'UTR of MMP-9 transcript. It is also worth noting that astrocytes can contribute to the increased level of MMP-9 mRNA in the molecular layer of dentate gyrus. However, an increase in the MMP-9 mRNA level in astrocytic processes was observed in the DG molecular layer $24 \mathrm{~h}$ after seizures induced by kainate (Konopacki et al., 2007), but not up to a few hours (see also Szklarczyk et al., 2002).

Many imaging studies confirmed that dendritically localized mRNAs were transported to the neuronal processes in mRNPs, or neuronal granules, i.e., large macromolecular complexes composed of mRNAs, RNA-binding proteins, and translational machinery including ribosomal proteins (Kiebler and Bassell, 2006). Delivery of mRNAs into distal neuronal processes and their local translation are tightly regulated, both as far as the specificity of the transported mRNAs as well as timing of the translation are concerned (Bramham and Wells, 2007; Wang et al., 2010). Herein, we have shown the presence of MMP-9 mRNA in dendrites and synapses of cultured hippocampal neurons, which is consistent with previous reports describing MMP-9 mRNA at the synapses of hippocampus after kainate-induced seizures (Konopacki et al., 2007). Moreover, we have demonstrated translocation of MMP-9 mRNA-containing neuronal granules to the dendrites after synaptic stimulation. Direct transport of MMP-9 mRNA in the living neuron was visualized with the MS2-GFP tagging system developed by Rook et al. (2000). Several transcripts can undergo activity-dependent transport to dendrites, e.g., $\alpha$ CaMKII, BDNF, eEF1A, and Arc mRNAs, to mention only a few, all proven to be critical for the synaptic plasticity (Rook et al., 2000; Messaoudi et al., 2007; Chiaruttini et al., 2008; Moon et al., 2008; Wang et al., 2008). mRNA polyadenylation is a major form of translation control for several dendritically localized 
transcripts (Richter, 2010). In the present study, we have shown that MMP-9 mRNA is polyadenylated within minutes after glutamate stimulation in synaptoneurosomes. This is similar to the previous reports on polyadenylation of tissue plasminogen activator, another secreted protease shown to be locally translated (Shin et al., 2004), and $\alpha$ CamKII polyadenylation occurring in the rat visual cortex in response to light exposure ( $\mathrm{Wu}$ et al., 1998). In neurons, activity-induced dendritic polyadenylation is regulated by $\mathrm{CPEB1}$, which interacts with the CPE consensus sequence (UUUUAU or similar) localized at the 3'UTR of the transcript (Mendez and Richter, 2001; Bramham and Wells, 2007). Indeed, the analysis of the $3^{\prime}$ UTR sequence of the rat MMP-9 transcript revealed the presence of two evolutionary conserved CPE consensus sequences (UUUUAU) in MMP-9 3' UTR. This makes MMP-9 a potential subject to CPEB dependent polyadenylation; however, more work is needed to determine whether activity-dependent polyadenylation of MMP-9 mRNA in synaptoneurosomes is regulated by CPEB.

The discovery of polysomes in dendritic spines raised the question of the identity and function of dendritic RNAs (Steward and Levy, 1982). Herein, we show that MMP-9 mRNA is associated with actively translating polyribosomes isolated from synaptoneurosomes. Synaptoneurosomes isolated from the rat neocortex and hippocampi were stimulated in vitro with glutamate and NMDA to promote polysome assembly. Fractionation on a sucrose gradient of nonstimulated and stimulated synaptoneurosomes was followed by RNA extraction from five fractions corresponding to mRNPs, monosome, light and heavy polysomes, and RNAcontaining granules. Radioactive RT-PCR confirmed the presence of MMP-9 mRNA in the polysomal fraction. Moreover, after NMDA receptor stimulation, MMP-9 mRNA shifted to the polysomal fraction that represents actively translating polyribosomes. Similar translocation to the polysomal fraction was shown previously for PSD-95, GluR1, and GluR2 mRNAs after DHPG (an agonist of group I metabotropic glutamate receptor) stimulation (Muddashetty et al., 2007).

The evidence that MMP-9 undergoes local synthesis is essential to understand its ability to regulate structural and functional spine remodeling. Synaptic MMP-9 translation may allow for the fast regulatory effect on spine morphology and receptor signaling. MMP-9 is produced at the synapse (in fact, at a subset of the synapses) and released to the extracellular space in an activity-dependent manner in a precursor form, where it is activated by proteolytic cleavage (Mazzieri et al., 1997; Bruno and Cuello, 2006). Direct influence of recombinant MMP-9 protein on dynamic spine changes has recently been reported (Bilousova et al., 2009; Michaluk et al., 2011; Wang et al., 2008). Activity-dependent release of MMP-9 at the activated synapse would facilitate its morphological changes and enable its reorganization. Studies of single-spine LTP induced by twophoton uncaging of glutamate demonstrate morphological changes at the level of single activated spines (Matsuzaki et al., 2004; Harvey and Svoboda, 2007; Lee et al., 2009). The present study strongly supports a role for activity-dependent dendritic transport of MMP-9 mRNA, translation, and release of MMP-9 protein. The locally secreted protein may then mediate extracellular remodeling necessary for establishing persistent modifications of synapse structure and function.

\section{References}

Bilousova TV, Dansie L, Ngo M, Aye J, Charles JR, Ethell DW, Ethell IM (2009) Minocycline promotes dendritic spine maturation and improves behavioural performance in the fragile X mouse model. J Med Genet 46:94-102.
Bozdagi O, Nagy V, Kwei KT, Huntley GW (2007) In vivo roles for matrix metalloproteinase- 9 in mature hippocampal synaptic physiology and plasticity. J Neurophysiol 98:334-344.

Bramham CR, Wells DG (2007) Dendritic mRNA: transport, translation and function. Nat Rev Neurosci 8:776-789.

Bruno MA, Cuello AC (2006) Activity-dependent release of precursor nerve growth factor, conversion to mature nerve growth factor, and its degradation by a protease cascade. Proc Natl Acad Sci U S A 103:6735-6740.

Cajigas IJ, Tushev G, Will TJ, tom Dieck S, Fuerst N, Schuman EM (2012) The local transcriptome in the synaptic neuropil revealed by deep sequencing and high-resolution imaging. Neuron 10:453-466.

Chiaruttini C, Sonego M, Baj G, Simonato M, Tongiorgi E (2008) BDNF mRNA splice variants display activity-dependent targeting to distinct hippocampal laminae. Mol Cell Neurosci 37:11-19.

Dzwonek J, Rylski M, Kaczmarek L (2004) Matrix metalloproteinases and their endogenous inhibitors in neuronal physiology of the adult brain. FEBS Lett 567:129-135.

Greenough WT, Klintsova AY, Irwin SA, Galvez R, Bates KE, Weiler IJ (2001) Synaptic regulation of protein synthesis and the fragile $\mathrm{X}$ protein. Proc Natl Acad Sci U S A 98:7101-7106.

Harvey CD, Svoboda K (2007) Locally dynamic synaptic learning rules in pyramidal neuron dendrites. Nature 450:1195-1200.

Hollingsworth EB, McNeal ET, Burton JL, Williams RJ, Daly JW, Creveling CR (1985) Biochemical characterization of a filtered synaptoneurosome preparation from guinea pig cerebral cortex: cyclic adenosine 3':5'monophosphate-generating systems, receptors, and enzymes. J Neurosci 5:2240-2253.

Ivanov A, Pellegrino C, Rama S, Dumalska I, Salyha Y, Ben-Ari Y, Medina I (2006) Opposing role of synaptic and extrasynaptic NMDA receptors in regulation of the extracellular signal-regulated kinases (ERK) activity in cultured rat hippocampal neurons. J Physiol 572:789-798.

Kiebler MA, Bassell GJ (2006) Neuronal RNA granules: movers and makers. Neuron 51:685-690.

Konopacki FA, Rylski M, Wilczek E, Amborska R, Detka D, Kaczmarek L, Wilczynski GM (2007) Synaptic localization of seizure-induced matrix metalloproteinase-9 mRNA. Neuroscience 150:31-39.

Krichevsky AM, Kosik KS (2001) Neuronal RNA granules: a link between RNA localization and stimulation-dependent translation. Neuron 32:683-696.

Lee SJ, Escobedo-Lozoya Y, Szatmari EM, Yasuda R (2009) Activation of CaMKII in single dendritic spines during long-term potentiation. Nature 458:299-304.

Li MZ, Elledge SJ (2007) Harnessing homologous recombination in vitro to generate recombinant DNA via SLIC. Nat Methods 4:251-256.

Matsuzaki M, Honkura N, Ellis-Davies GC, Kasai H (2004) Structural basis of long-term potentiation in single dendritic spines. Nature 429:761-766.

Mazzieri R, Masiero L, Zanetta L, Monea S, Onisto M, Garbisa S, Mignatti P (1997) Control of type IV collagenase activity by components of the urokinase-plasmin system: a regulatory mechanism with cell-bound reactants. EMBO J 16:2319-2332.

Meighan PC, Meighan SE, Davis CJ, Wright JW, Harding JW (2007) Effects of matrix metalloproteinase inhibition on short- and long-term plasticity of Schaffer collateral/CA1 synapses. J Neurochem 102:2085-2096.

Mendez R, Richter JD (2001) Translational control by CPEB: a means to the end. Nat Rev Mol Cell Biol 2:521-529.

Messaoudi E, Ying SW, Kanhema T, Croll SD, Bramham CR (2002) Brainderived neurotrophic factor triggers transcription-dependent, late phase long-term potentiation in vivo. J Neurosci 22:7453-7461.

Messaoudi E, Kanhema T, Soulé J, Tiron A, Dagyte G, da Silva B, Bramham CR (2007) Sustained Arc/Arg3.1 synthesis controls long-term potentiation consolidation through regulation of local actin polymerization in the dentate gyrus in vivo. J Neurosci 27:10445-10455.

Michaluk P, Kolodziej L, Mioduszewska B, Wilczynski GM, Dzwonek J, Jaworski J, Gorecki DC, Ottersen OP, Kaczmarek L (2007) Betadystroglycan as a target for MMP-9, in response to enhanced neuronal activity. J Biol Chem 282:16036-16041.

Michaluk P, Wawrzyniak M, Alot P, Szczot M, Wyrembek P, Mercik K, Medvedev N, Wilczek E, De Roo M, Zuschratter W, Muller D, Wilczynski GM, Mozrzymas JW, Stewart MG, Kaczmarek L, Wlodarczyk J (2011) Influence of matrix metalloproteinase MMP-9 on dendritic spine morphology. J Cell Sci 124:3369-3380.

Moon IS, Cho SJ, Lee H, Seog DH, Jung YW, Jin I, Walikonis R (2008) 
Upregulation by $\mathrm{KCl}$ treatment of eukaryotic translation elongation factor 1A (eEF1A) mRNA in the dendrites of cultured rat hippocampal neurons. Mol Cells 25:538-544.

Muddashetty RS, Keliæ S, Gross C, Xu M, Bassell GJ (2007) Dysregulated metabotropic glutamate receptor-dependent translation of AMPA receptor and postsynaptic density-95 mRNAs at synapses in a mouse model of fragile X syndrome. J Neurosci 27:5338-5348.

Nagy V, Bozdagi O, Matynia A, Balcerzyk M, Okulski P, Dzwonek J, Costa RM, Silva AJ, Kaczmarek L, Huntley GW (2006) Matrix metalloproteinase-9 is required for hippocampal late-phase long-term potentiation and memory. J Neurosci 26:1923-1934.

Okulski P, Jay TM, Jaworski J, Duniec K, Dzwonek J, Konopacki FA, Wilczynski GM, Sánchez-CapeloA, Mallet J, Kaczmarek L (2007) TIMP-1 abolishes MMP-9-dependent long-lasting long-term potentiation in the prefrontal cortex. Biol Psychiatry 62:359-362.

Panja D, Dagyte G, Bidinosti M, Wibrand K, Kristiansen AM, Sonenberg N, Bramham CR (2009) Novel translational control in Arc-dependent long term potentiation consolidation in vivo. J Biol Chem 284:31498-31511.

Richter JD (2010) Translational control of synaptic plasticity. Biochem Soc Trans 38:1527-1530.

Rivera S, Khrestchatisky M, Kaczmarek L, Rosenberg GA, Jaworski DM (2010) Metzincin proteases and their inhibitors: foes or friends in nervous system physiology? J Neurosci 30:15337-15357.

Rook MS, Lu M, Kosik KS (2000) CaMKIIalpha 3' untranslated regiondirected mRNA translocation in living neurons: visualization by GFP linkage. J Neurosci 20:6385-6393.

Rylski M, Amborska R, Zybura K, Konopacki FA, Wilczynski GM, Kaczmarek L (2008) Yin Yang 1 expression in the adult rodent brain. Neurochem Res 33:2556-2564.

Scheetz AJ, Nairn AC, Constantine-Paton M (2000) NMDA receptor- mediated control of protein synthesis at developing synapses. Nat Neurosci 3:211-216.

Shin CY, Kundel M, Wells DG (2004) Rapid, activity-induced increase in tissue plasminogen activator is mediated by metabotropic glutamate receptor-dependent mRNA translation. J Neurosci 24:9425-9433.

Steward O, Levy WB (1982) Preferential localization of polyribosomes under the base of dendritic spines in granule cells of the dentate gyrus. J Neurosci 2:284-291.

Szklarczyk A, Lapinska J, Rylski M, McKay RD, Kaczmarek L (2002) Matrix metalloproteinase-9 undergoes expression and activation during dendritic remodeling in adult hippocampus. J Neurosci 22:920-930.

Wang DO, Martin KC, Zukin RS (2010) Spatially restricting gene expression by local translation at synapses. Trends Neurosci 33:173-182.

Wang XB, Bozdagi O, Nikitczuk JS, Zhai ZW, Zhou Q, Huntley GW (2008) Extracellular proteolysis by matrix metalloproteinase- 9 drives dendritic spine enlargement and long-term potentiation coordinately. Proc Natl Acad Sci U S A 105:19520-19525.

Wilczynski GM, Konopacki FA, Wilczek E, Lasiecka Z, Gorlewicz A, Michaluk P, Wawrzyniak M, Malinowska M, Okulski P, Kolodziej LR, Konopka W, Duniec K, Mioduszewska B, Nikolaev E, Walczak A, Owczarek D, Gorecki DC, Zuschratter W, Ottersen OP, Kaczmarek L (2008) Important role of matrix metalloproteinase 9 in epileptogenesis. J Cell Biol 180:1021-1035.

Wu L, Wells D, Tay J, Mendis D, Abbott MA, Barnitt A, Quinlan E, Heynen A, Fallon JR, Richter JD (1998) CPEB-mediated cytoplasmic polyadenylation and the regulation of experience-dependent translation of alphaCaMKII mRNA at synapses. Neuron 21:1129-1139.

Zagulska-Szymczak S, Filipkowski RK, Kaczmarek L (2001) Kainateinduced genes in the hippocampus: lessons from expression patterns. Neurochem Int 38:485-501. 